\title{
CLINICAL EXPERIENCE WITH IBUPROFEN IN THE TREATMENT OF RHEUMATOID ARTHRITIS
}

\author{
BY \\ T. M. CHALMERS* \\ Rheumatic Diseases Unit, Northern General Hospital, Edinburgh
}

The search continues for a compound with the anti-inflammatory and analgesic properties of aspirin, but without its occasionally troublesome side-effects. Ibuprofen (2-4'-isobutylphenylpropionic acid) is the latest member of a series of phenylalkanoic acids to be submitted for clinical trial. Boardman, Nuki, and Dudley Hart (1967) concluded that in twenty patients with rheumatoid arthritis Ibuprofen, when given in a daily dosage of $0.9 \mathrm{~g}$., did not exhibit a significant therapeutic effect when compared with placebo. Similarly, in nineteen patients with osteoarthritis, these authors found that clinically significant improvement was not obtained when Ibuprofen was given in a daily dosage of $0.6 \mathrm{~g}$. daily for 14 days. Thompson, Fox, and Newell (1967), however, reported that Ibuprofen, in daily dosages of up to $0.6 \mathrm{~g}$., was effective in relieving pain and morning stiffness in patients with rheumatoid arthritis, and useful for patients unable to take aspirin because of dyspepsia.

The purpose of this paper is to report the results of the initial pilot trials of Ibuprofen in the treatment of patients with rheumatoid arthritis, together with a review of the effects of long-term administration of the drug.

\section{Methods}

Ibuprofen was given to six in-patients in each of two short clinical trials, and subsequently substituted for aspirin for maintenance therapy in a group of 27 outpatients.

\section{(1) In-Patient Trial}

Six patients, each with classical or definite rheumatoid arthritis as defined by the diagnostic criteria of the American Rheumatism Association (Ropes, Bennett, \footnotetext{
*Present address: Rheumatism Research Clinic, Royal Infirmary,
Manchester 13.
}

Cobb, Jacox, and Jessar, 1959), were admitted to each trial. The object of the first trial was to compare the effects of the following drug regimens given in random sequence for periods of one week:

(a) Aspirin in a dosage of $3.6 \mathrm{~g}$. daily

(b) Ibuprofen in a dosage of $0.3 \mathrm{~g}$. daily

(c) Ibuprofen in a dosage of $0.6 \mathrm{~g}$. daily.

In the second trial the following drug regimens were compared in similar fashion:

(a) Aspirin in a dosage of $3.6 \mathrm{~g}$. daily

(b) Ibuprofen in a dosage of $0.6 \mathrm{~g}$. daily

(c) Ibuprofen in a dosage of $0.9 \mathrm{~g}$. daily.

In each trial the point of entry and sequence of treatments were randomized and patient and observer remained unaware of which regimen was being given at any one time. The drugs were put up in identical capsules, dummy capsules of lactose being used to achieve a daily total of twelve in each week of treatment. All patients were receiving routine treatment with rest in bed, ward exercises, conservative splinting, and salicylates before entry. Patients receiving corticosteroids were excluded, and no patient received oral or parenteral iron during the trial period.

Clinical assessments were carried out daily. These included measurement of grip strength and joint tenderness (i.e. pressure tolerance) as previously described (Chalmers, 1963). In addition, joint swelling in two clinically affected interphalangeal joints was measured with a set of jeweller's rings. Measurements were made for a few days before entry to accustom the patient to the methods employed.

Laboratory assessments were carried out on entry and at the end of each week of the trial period. They included measurement of haemoglobin concentration (Hb), erythrocyte sedimentation rate (ESR), total leucocyte count (WBC) and platelet count; serum bilirubin; serum glutamic-oxalacetic transaminase (SGOT) and serum glutamic-pyruvic transaminase (SGPT); serum uric acid; prothrombin activity. The urine was tested for glucose, albumin, and urobilinogen, and was examined microscopically. The faeces were tested for occult blood. 
(2) Maintenance Therapy in Out-Patients

Ibuprofen was substituted for aspirin in the treatment of 27 patients (20 female, 7 male) with rheumatoid arthritis attending as out-patients. The average age was 60.6 years, and the average duration of arthritis 7 years. No patient was receiving maintenance therapy with corticosteroids, but twelve were taking chloroquine phosphate in a daily dose of $250 \mathrm{mg}$. Four patients received Ibuprofen for 3 months or less; seventeen patients for 4-12 months; and six patients for over 12 months. The average daily dose of Ibuprofen was $600 \mathrm{mg}$. (range 200-1,200).

Patients were seen initially every 2 weeks, and after 3 months at monthly intervals. Clinical assessment at each visit included measurement of body weight, grip strength, and joint tenderness and swelling, and the patient's estimate of the duration of morning stiffness was noted. Laboratory investigations included measurement of $\mathrm{Hb}$, ESR, WBC, platelet count, and sensitized sheep cell titre. Tests of liver function included estimation of serum bilirubin, GOT, and alkaline phosphatase, and the blood urea and serum uric acid were also determined. The urine was tested for glucose, albumin, and urobilinogen, and was examined microscopically. Abnormal reactions and any alteration in other details of treatment were noted.

Patient and observer were aware that a new preparation was being taken, and other forms of supportive treatment were not withheld. For example, two patients received intra-articular injections of hydrocortisone and five received a course of parenteral iron during the period of observation.

\section{Results}

\section{(1) Pilot Trials in In-patients}

(a) Aspirin $3.6 \mathrm{~g}$. v. Ibuprofen $0.3 \mathrm{~g} . \mathrm{v}$. Ibuprofen $0.6 \mathrm{~g}$.-From the weekly averages of daily measurements, an overall average for each treatment can be obtained for the 3-week period of trial (Table I). Very little difference is seen in the results obtained with each treatment, and examination of the graphs prepared for each patient and showing the pattern of change in daily measurements revealed gradual slight improvement throughout the period of trial irrespective of the sequence of treatments.

(b) Aspirin $3.6 \mathrm{~g} . \mathrm{v}$. Ibuprofen $0.6 \mathrm{~g}$. v. Ibuprofen $0.9 \mathrm{~g}$.- Similar overall averages for this trial are also shown in Table I. Again very small differences are noted both between aspirin and Ibuprofen and between the two dosages of Ibuprofen employed. The graphs of daily measurement again tended to show gradual improvement unrelated to sequence of treatment.

No constant trend was noted in the results of laboratory investigations related to treatment. $\mathrm{Hb}, \mathrm{ESR}, \mathrm{WBC}$, and platelet counts were largely unaffected by any drug regimen. Prothrombin activity was lowest after treatment with aspirin in four patients. Significant faecal blood loss did not occur, and no urinary abnormalities were noted. Serum uric acid and bilirubin levels bore no constant relationship to drug regimen. Serum GOT and/or GPT levels were raised in two patients on entry, but fell to within normal limits during the course of the trial.

\section{(2) Maintenance Therapy in Out-Patients}

Clinical Assessments.-The results of clinical assessments are set out in Table II. Grip strength improved in 21 of the 27 patients, with a mean improvement of $34 \mathrm{~mm} . \mathrm{Hg}$, but improvement in the other indices was less constant and less marked. In particular, the overall improvement in joint swelling was very small.

\section{Laboratory Studies}

(a) With regard to measurements of $\mathrm{Hb}, \mathrm{ESR}$, WBC, and platelet counts, and to the demonstration of rheumatoid factor by the sensitized sheep cell test, no constant trends were observed. In no patient was there any evidence of haematological toxicity.

(b) Liver Function. The SGOT was elevated to over 40 Sigma Frankel units on three isolated

TABLE I

CLINICAL ASSESSMENTS IN PILOT TRIALS

Overall Averages for Each Treatment

\begin{tabular}{|c|c|c|c|c|c|c|c|c|}
\hline \multirow{2}{*}{$\frac{\text { Pilot Trial }}{\text { Treatment }}$} & & \multirow{2}{*}{$\cdots$} & \multicolumn{3}{|c|}{1} & \multicolumn{3}{|c|}{2} \\
\hline & & & Aspirin $3.6 \mathrm{~g}$ & Ibuprofen $\mathbf{0 . 3 \mathrm { g }}$ & Ibuprofen $0.6 \mathrm{~g}$ & Aspirin $3.6 \mathrm{~g}$. & Ibuprofen $3.6 \mathrm{~g}$. & Ibuprofen $0.9 \mathrm{~g}$. \\
\hline \multirow{3}{*}{$\begin{array}{l}\text { Clinical } \\
\text { Sign }\end{array}$} & \multicolumn{2}{|c|}{$\underset{\text { (mm.Hg) }}{\text { Grip Strength }}$} & 171 & 165 & 167 & 187 & 176 & 177 \\
\hline & \multicolumn{2}{|c|}{$\begin{array}{l}\text { Joint Tenderness } \\
\text { (pressure tolerance } \\
\text { in lb./sq. in.) }\end{array}$} & $13 \cdot 6$ & $11 \cdot 7$ & $12 \cdot 8$ & $16 \cdot 8$ & $16 \cdot 5$ & $16 \cdot 6$ \\
\hline & \multicolumn{2}{|c|}{$\begin{array}{l}\text { Joint Swelling } \\
\text { (ring size) }\end{array}$} & $19 \cdot 6$ & $19 \cdot 7$ & $19 \cdot 4$ & $21 \cdot 0$ & $21 \cdot 0$ & $20 \cdot 9$ \\
\hline
\end{tabular}


TABLE II

MAINTENANCE THERAPY: CLINICAL ASSESSMENTS

\begin{tabular}{|c|c|c|c|c|c|c|c|c|c|c|}
\hline \multirow{2}{*}{\multicolumn{2}{|c|}{$\begin{array}{l}\text { Clinical Sign } \\
\text { Mean Values }\end{array}$}} & \multirow{3}{*}{$\cdots$} & \multicolumn{2}{|c|}{$\begin{array}{c}\text { Grip Strength } \\
\text { (mm. Hg) }\end{array}$} & \multicolumn{2}{|c|}{$\begin{array}{c}\text { Joint Tenderness } \\
\text { (pressure tolerance } \\
\text { in lb./sq. in.) }\end{array}$} & \multicolumn{2}{|c|}{$\begin{array}{l}\text { Joint Swelling } \\
\text { (ring size) }\end{array}$} & \multicolumn{2}{|c|}{$\begin{array}{c}\text { Morning Stifiness } \\
\text { (min.) }\end{array}$} \\
\hline & & & Initial & Final & Initial & Final & Initial & Final & Initial & Final \\
\hline & & & 139 & 173 & $8 \cdot 3$ & $12 \cdot 7$ & 18 & $17 \cdot 7$ & 66 & 49 \\
\hline \multirow{3}{*}{$\begin{array}{l}\text { No. of } \\
\text { Patients }\end{array}$} & \multicolumn{2}{|c|}{ Improved } & \multicolumn{2}{|c|}{21} & \multicolumn{2}{|c|}{20} & \multicolumn{2}{|c|}{15} & \multicolumn{2}{|c|}{12} \\
\hline & \multicolumn{2}{|c|}{ Unchanged } & \multicolumn{2}{|c|}{1} & \multicolumn{2}{|c|}{1} & \multicolumn{2}{|c|}{4} & \multicolumn{2}{|c|}{8} \\
\hline & \multicolumn{2}{|c|}{ Deteriorated } & \multicolumn{2}{|c|}{5} & \multicolumn{2}{|c|}{6} & \multicolumn{2}{|c|}{8} & \multicolumn{2}{|c|}{7} \\
\hline
\end{tabular}

occasions in three patients $(43,43$, and 50 units), but there was no sustained elevation in any patient.

With regard to the measurement of serum bilirubin, no overall tendency to rise was noted. In one patient, in whom the serum level was $0.7 \mathrm{mg} . / 100$ $\mathrm{ml}$. initially, it varied between 0.1 and $1.3 \mathrm{mg} . / 100$ $\mathrm{ml}$. during the period of observation. In this individual the SGOT was slightly raised (43 units) on one occasion, but otherwise values were normal.

Serum levels of alkaline phosphatase activity greater than 13 King Armstrong units were noted in six patients, the highest level recorded being $18 \mathrm{KA}$ units. In none of the six patients, however, was there a simultaneous increase in levels of serum bilirubin or SGOT, and in none was the level of alkaline phosphatase activity persistently elevated.

(c) Persistent elevation of serum uric acid levels occurred in two patients. Initially, levels of 1.8 and $2.7 \mathrm{mg} . / 100 \mathrm{ml}$. were recorded. After 14 months on $600 \mathrm{mg}$. Ibuprofen daily the serum levels were 7.9 and $6.7 \mathrm{mg} . / 100 \mathrm{ml}$. respectively.

(d) No constant changes in the level of blood urea were noted. In three patients the pre-treatment level was raised.

(e) On routine urine testing, albumin was detected on five occasions with associated pyuria and significant growth on culture, and on two occasions without obvious cause. Tests for urobilinogen were negative. On microscopy no casts were seen, but scanty red blood cells were noted on two occasions without obvious cause.

\section{Side-Effects and Withdrawals}

(a) In-Patient Trials.-Two patients complained of gastrointestinal symptoms (flatulent dyspepsia, vomiting) while taking aspirin, and one while taking

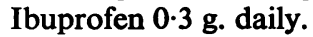

Four patients had noted tinnitus and deafness while taking aspirin $4.5 \mathrm{~g}$. daily before entry, but only one complained of these symptoms while taking aspirin during the trial. No patient noted tinnitus or deafness while taking Ibuprofen.

No skin rashes were observed during the trial period.

Two patients required additional paracetamol for control of joint pain while taking Ibuprofen.

(b) Maintenance Therapy.-Gastrointestinal symptoms occurred in four patients. Three of these complained of nausea, associated in one with vague abdominal pain, and in another with subsequent vomiting and diarrhoea, which settled on reduction of the daily dose from 600 to $400 \mathrm{mg}$. In the fourth patient abdominal pain was more persistent and a duodenal ulcer was demonstrated on radiographs taken after a barium meal. This patient, who had had ulcer symptoms in the past, had increased his daily dose of Ibuprofen to $1,200 \mathrm{mg}$. without instruction.

No patient complained of tinnitus or deafness while taking Ibuprofen.

Skin rash occurred in one patient. This took the form of an itchy macular erythema, distributed mainly on the arms, thighs, and abdomen, and developing after 2 weeks' treatment with $400 \mathrm{mg}$. daily. The rash subsided within a few days of discontinuing the drug.

Treatment was discontinued in seven patients. Two were symptom free and their arthritis clinically inactive after 8 and 11 months of treatment respectively. In two others Ibuprofen was discontinued on request after less than one month because of poor relief of pain. One patient discontinued after 3 months, preferring another antiinflammatory drug prescribed by the family doctor. Treatment was also discontinued in the patient who developed a skin rash and in the patient with symptoms from duodenal ulcer.

\section{Discussion}

The assessment of the clinical effectiveness of any new anti-inflammatory compound in the treatment 
of rheumatoid arthritis must include comparison with aspirin, which remains the safest and most effective single remedy. Does the preparation under trial show any marked superiority in affording symptomatic relief? If not, can it at least provide comparable relief from symptoms and remain free from troublesome side-effects? If it can do this, is it a safe drug to give to patients over a long period, or is there any evidence of cumulative toxicity? The results reported here of clinical experience with Ibuprofen go some way to answering these important questions.

First, it is clear from the results of the trials in in-patients that in the dosages employed Ibuprofen shows no superiority over aspirin in standard dosage, and there is some suggestion that its analgesic properties are poor. On the other hand, it is clear that Ibuprofen can take over from aspirin satisfactorily without any exacerbation of joint symptoms and during the short periods of trial it gave rise to fewer side-effects.

This possible advantage, however, was not convincingly maintained when Ibuprofen was substituted for aspirin in the maintenance therapy of outpatients. The results of objective and subjective clinical assessments did suggest satisfactory control of symptoms in the majority of patients, but sideeffects did occur and were on occasion troublesome. It should be added, however, that three patients previously intolerant of aspirin because of gastric irritation did obtain satisfactory relief with Ibuprofen without dyspepsia.

With regard to the third question-is Ibuprofen a safe drug to give over a prolonger period?-the results of regular haematological and biochemical screening provide no evidence to date to suggest toxicity. In particular, there has been no evidence to suggest impairment of renal or hepatic function, nor of bone marrow depression.

It is concluded that Ibuprofen, although showing no superiority over aspirin, nor devoid of side-effects, may merit trial in the symptomatic treatment of rheumatoid arthritis in patients in whom standard remedies prove unacceptable.

\section{Summary}

(1) Ibuprofen (2-4'-isobutylphenylpropionic acid) has been compared with aspirin in double-blind cross-over clinical trials in twelve patients with rheumatoid arthritis. No great differences have been noted in the results of clinical assessment at the dosage levels employed.

(2) Ibuprofen has been substituted for aspirin in the routine maintenance therapy of 27 patients with rheumatoid arthritis for periods of up to 17 months. Satisfactory symptomatic relief has been maintained in the majority. Side-effects have included gastrointestinal symptoms in four patients (with re-activation of duodenal ulcer in one), and skin rash in one patient. Biochemical and haematological screening has yielded no evidence of toxicity.

(3) It is concluded that Ibuprofen may merit consideration for patients with rheumatoid arthritis in whom standard remedies prove unacceptable.

During the period of these trials the Rheumatic Diseases Unit was in receipt of grants from the Medical Research Council, the Arthritis and Rheumatism Council, the Nuffield Foundation, and Boots Pure Drug Company Limited, who made available supplies of Ibuprofen.

\section{REFERENCES}

Boardman, P. L., Nuki, G., and Dudley Hart, F. (1967). Ann. rheum. Dis., 26, 560 (Ibuprofen in the treatment of rheumatoid arthritis and osteo-arthritis).

Chalmers, T. M. (1963). Ibid., 22, 358 (Clinical trials?of a new drug, Ibufenac, in the treatment of rheumatoid arthritis. A preliminary report).

Ropes, M. W., Bennett, G. A., Cobb, C., Jacox, R., and Jessar, R. (1959). Ibid., 18, 49 (Diagnostic criteria for rheumatoid arthritis. 1958 revision).

Thompson, M., Fox, H. M., and Newell, D. J. (1967). Sixth European Congress of Rheumatology, Lisbon (Ibuprofen in the treatment of rheumatoid arthritis). 


\section{L'Ibuprofène dans la polyarthrite rhumatoïde}

\section{RÉSUMÉ}

(1) L'Ibuprofène (acide 2-4'-isobutylphenylpropionique) a été comparé à l'aspirine dans les essais cliniques faites par la méthode "double-blind cross-over" chez douze malades atteints de polyarthrite rhumatoïde. Aucune grande différence n'a été notée dans les résultats d'évaluation clinique aux dosages employés.

(2) L'Ibuprofène a été substitué à l'aspirine dans la thérapie routinière de soutien de 27 malades atteints de polyarthrite rhumatoïde pendant des périodes allant jusqu'à 17 mois. Un soulagement symptomatique satisfaisant a été maintenu dans la majorité des cas. Les effets secondaires ont inclu des symptômes gastro-intestinaux chez quatre malades (avec réapparition d'un ulcère duodénal chez l'un deux) et une éruption cutanée chez un autre. Les tests biochimiques et hématologiques n'ont pas montré de signes de toxicité.

(3) Il est conclu que l'Ibuprofène mérite, peut-être, d'être considéré pour les malades atteints de polyarthrite rhumatoïde chez lesquels les traitements standards ne sont pas acceptables.

\section{Experiencia clínica con Ibuprofen en el tratamiento de poliartritis reumatoide}

\section{SUMARIO}

(1) El Ibuprofen (ácido isobutilfenilpropionico 2-4') ha sido comparado con la aspirina en pruebas clínicas cruzadas dobleciego en doce pacientes con poliartritis reumatoide. No se han notado grandes diferencias en los resultados del avalúo clínico a los niveles de dosificación empleados.

(2) El Ibuprofen ha sido substituido por aspirina en el tratamiento regular de 27 pacientes con poliartritis reumatoide, durante períodos de hasta 17 meses. En la mayoría se ha mantenido alivio sintomático satisfactorio. Los efectos secundarios han abarcado síntomas gastrointestinales en cuatro pacientes (con reactivación de úlcera duodenal en uno) y erupción de la piel en un paciente. La depuración bioquímica y hematológica no ha dado evidencia de toxicidad.

(3) Se llega a la conclusión de que el Ibuprofen quizá merezca ser considerado para pacientes con poliartritis reumatoide, en los cuales los remedios corrientes han resultado inaceptables. 